doi: 10.52370/TISC21535SZ

\title{
PSYCHOLOGICAL APPROACHES IN PSYCHOTHERAPY AND HEALTH TOURISM DURING COVID 19 PANDEMIC
}

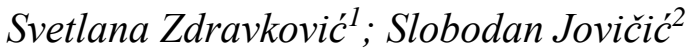

\begin{abstract}
During the COVID-19 pandemic, the psychological approaches in both psychotherapy and health tourism have kept their essence and importance, but the experts are being confronted with challenges that demand changes. The goal of the paper is to examine newly established circumstances caused by COVID-19 pandemic as well as their influence on psychotherapy and health tourism - areas of great value for maintaining mental and physical health and the wellbeing. The modifications in the psychological approach could be connected with: the use of new technologies, spending time outdoor with an obligatory social distancing, the reduction and lack of the physical contact, etc. The use of creativity in psychotherapy and health tourism, expressed, among other valuable ways, by the use of active imagination, a well known method of analytical psychology, is being discussed and the hermeneutic method has been applied for analyzing the positive effect and benefits on individuals 'wellbeing and health.
\end{abstract}

Key Words: COVID-19, forest medicine, psychotherapy, health tourism, active imagination, Jungian psychology

JEL classification: I31

\section{Introduction - COVID-19 pandemic situation}

The COVID-19 pandemic, for more than a year, has been influencing peoples' lives greatly. On the one side, the life continues as usual, the same obligations have to be done, the same needs have to be fulfilled; children,

\footnotetext{
${ }^{1}$ Svetlana Zdravković, dr, doctor of psychology, Jungian analyst, Specialist in medical psychology, Institute of mental health, Palmotićeva 37, 11000 Belgrade, Serbia, +381638265346, svetlana.zdravkovic@imh.org.rs

2 Slobodan T. Jovičić, dr, professor, School of Electrical Engineering, University of Belgrade, 11000 Belgrade, Serbia, and Institute "Center of Life Activities Advancement", 11000 Belgrade, Serbia, jovicic@etf.rs
} 
teenagers, adolescents, adults and older people continue their processes of individuation (Samuels, 2000). The same archetypal (Jung, 1959) situations of: being born or giving birth, growth, getting old, facing death, getting married, becoming a parent, loosing someone, getting into a transitional period, etc., are still happening within the same universal patterns. On the other side, the circumstances are being hugely changed. Our sense of identity and stability has been seriously shaken. The "old ways" do not work properly anymore and require adaptation. We still search for the "new ways" while finding ourselves somewhere "betwixt and between" (Stein, 1996).

Figure 1: Luminal

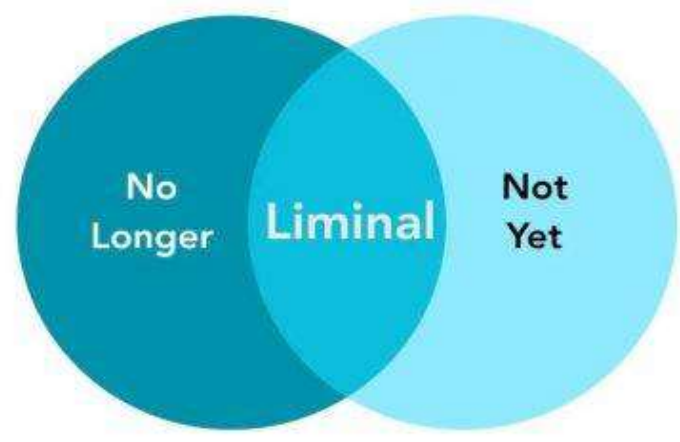

Source: Digby Scott, (2019), Master the Liminal, https://digbyscott.com/2019/09/26/master-the-liminal/, (20 January 2021)

During the period of the pandemic, we are being pushed into the state of constant flow. Analytical psychologists would say that we are floating in liminality (Stein, 2003). The certainty and stability which we felt within and around us while approaching different life situation are losing its usual form. Nothing is as it used to be. We exited the stable faze and are being launched into the dark see of uncertainty (Figure 1). We entered into a transitional period (Stein, 2006). It could not be said how long it will last. No one knows if the world will ever be as it was before. It could not be predicted with a certainty how the world will look like after (if) the COVID 19 pandemic is over. We can see a huge number of ifs, maybes, perhaps, it depends, nobody knows; it may but doesn't have to be, etc. Nevertheless, there is just a few: it certainly is or will be.

In this new state of facts, a stable sense of personal and group identity can be seriously shaken. This could be followed by heightened psychological difficulties and problems. A person does not feel to have something firm to 
hold onto jet and had already let go of the previous secure "port" (Figure 2).

Figure 2: Luminality

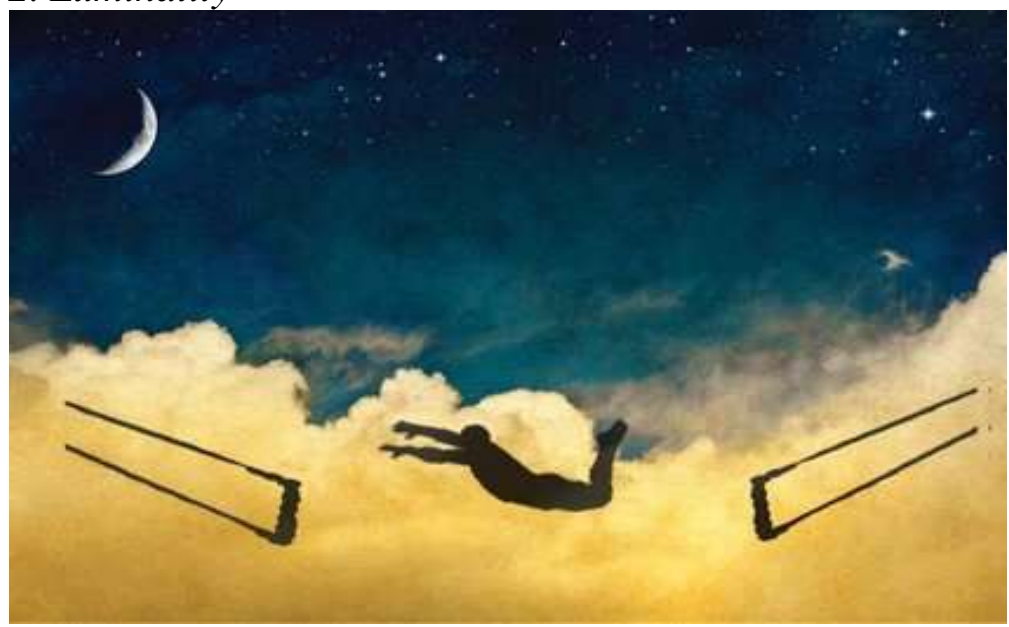

Source: Learning Spaces, (2021), The Liminal Space, http://aspacetoinspire.weebly.com/the-liminal-space.html (20 January 2021)

This situation, burdened with uncertainties, could evoke different psychological difficulties and problems. A person could become anxious, tense, angry, depressive, aggressive, and preoccupied about his own or the health of others, worried, obsessive, disoriented, confused, frightened, etc. (Rajković et al., 2018). Somatizations could appear too. In order to cope with the newly established way of living, working, going to school, socializing, behaving and feeling happier, a lot of people nowadays need some help.

The goal of the paper is the examination of newly established circumstances caused by COVID-19 pandemic and their influence on psychotherapy and health tourism.

\section{Flora, fauna and merryweather $v s$ maleficient}

In order to prevent potential disorders and to work on them before they develop more difficult forms, experts in both above mentioned fields psychotherapy and health tourism - have to work hard to reduce "the curse of the virus", like it happened in the "Sleeping beauty". This fairytale could be seen as a beautiful metaphor (Crowther et al., 1998) for the situation we 
are facing nowadays. In Walt Disney`s film from 1959, good fairies named Flora, Fauna and Merry-weather are helping princess Aurora to survive the curse and of the evil fairy Maleficent. The names of the fairies are not without sense. They are profoundly connected with nature.

Being estranged from the nature in our inner as well as in our external worlds, it is not surprising that the mankind is facing a lot of serious problems. One of them, a COVID-19, we are facing since the beginning of the last year. Among humans, simultaneously growing tendencies of emotional alienation and of treating the other as a means of fulfilling one's own needs could be seen. Nurturing what we have inside us and with others has been put into the second plane since the value and the acquisitions of material things are growing. A similar negligence of the essential things could be noticed in the nature that surrounds us. We are not taking a good care about our air, forests, animals, parks and trees in our cities. Hence, our inner and outer nature is suffering. The "evil fairy Maleficent" (seen as a negative part of a Mother archetype (Fiery, 1991)) "has put her curse" in the form of the virus onto people. On the other side, Gaia, a Mother Earth (seen psychologically as a positive side of a Mother archetype) is withdrawn, suffering.

But, we still have "three good fairies" on our side. Flora, Fauna and Merryweather can help us. By getting people in contact with their own nature during psychotherapy and encouraging them to go into the nature within health tourism, experts from both mentioned areas could do a lot if working together today. Being included profoundly in both areas, the authors have a strong impression that health tourism and psychotherapy are the members of the same time. Joined together, with nurturing and encouraging the advantages of each other the maximum of the possible effects on the health (psychical and physical) could be accomplished.

\section{Health tourism before and in the time of COVID-19}

A forest medicine within the health tourism is seen as a very useful approach that could enable healthy individuals as well as those with some difficulties to nurture themselves and to improve the quality of their lives. Shinrin yoku movement ("forest bathing"), very popular in Japan from the mid 80-is in the XX century, has flourished again all over the world. In Japan and some other countries, spending time in the forest has been prescribed to patients as an official method of improving ones' health. 
In the text about the role of psychotherapist in the individual approach to the client within the health tourism (Zdravković, 2018) the author is discussing the immense value of the "cure forest" and "healing forest" approaches within the health tourism. The first notion (cure forest) is connected with healthy persons without obvious mental and physical difficulties. Although without health issues, these persons could have huge benefits from spending time in the forest ambient. By being in this special atmosphere, healthy individuals could regain their psychological energy and get in a better contact with his inner nature. That could have a lot of positive effects on their everyday life related to their social, emotional and professional aspects.

On the other side, the concept of a "healing forest" is more adapted to the person that has some health issues. People suffering from anxiety, depression or some other psychiatric disorders as well as from various somatic illnesses, could establish better connections with their unconscious and a creative potential that could contribute to their healing.

Within both mentioned frameworks, spending time in the forest ambient has numerous health benefits. It has been shown that, among many other things, a blood pressure becomes more balanced, people feel more relaxed, energized and satisfied. Engaging all senses while being in the forest improves the overall state of the organism. The pleasant sensations are evoked by listening the sounds of birds, forest springs, wind, movements of the leaves etc. Noticing all the different colors and shapes of the leaves, trees and other plants and living creatures is a feast for the tired eyes habituated to the city`s grayness and dullness. The possibility to focus on the bodily sensations and to be in the body (embodied) much more than usual is an enriching experience - especially nowadays. Touching and hugging the trees, can return us to ourselves and could have a strong grounding effect.

A fairytale-like atmosphere of a forest inspires us to dive into liminality where stable images that we have about us begin to fade, opening at the same time a door towards new ways of perceiving and experiencing our inner as well as the nature that surrounds us. The mythical forest ambient could also reconnect people with their inner child (Jung, 1954) and hence, with their (often forgotten) creativity. Within Jungian psychology and creativity (as in other depth psychotherapeutic approaches) the immense power of the creativity (Jung, 1960; Gaillard, 2006) is well known and much appreciated. Here, we could find a mythical place where health 
tourism (embodied in the forest medicine) and psychotherapy meet and overlap (Figure 3).

Figure. 3: Overlap between psychotherapy and health tourism

Source: Authors

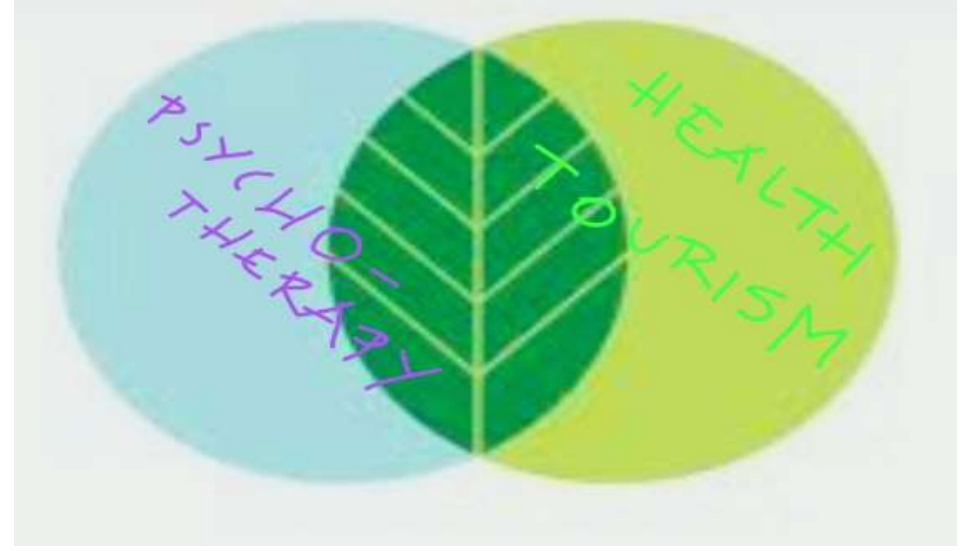

Figure 4: Active imagination-1

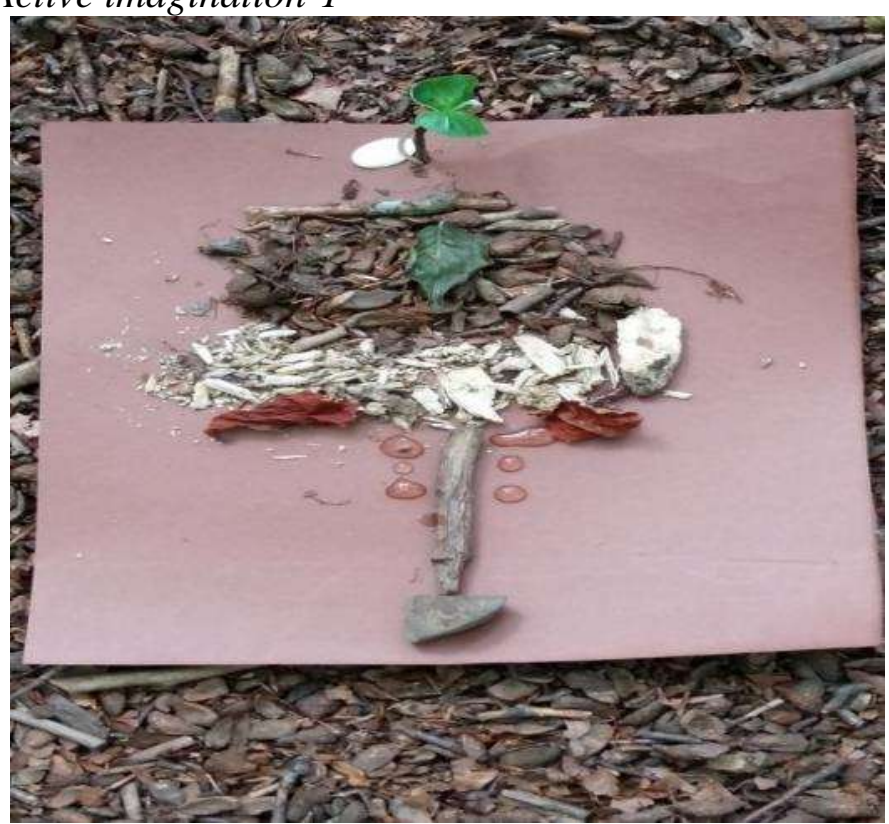

Source: Zdravković, S. (2018). The Role of Psychotherapist in the Individual Approach to the Client within the Health Tourism. TISC Tourism International Scientific Conference, Vrnjačka Banja, 3(2), 697713 
Figure 5: Active imagination-2
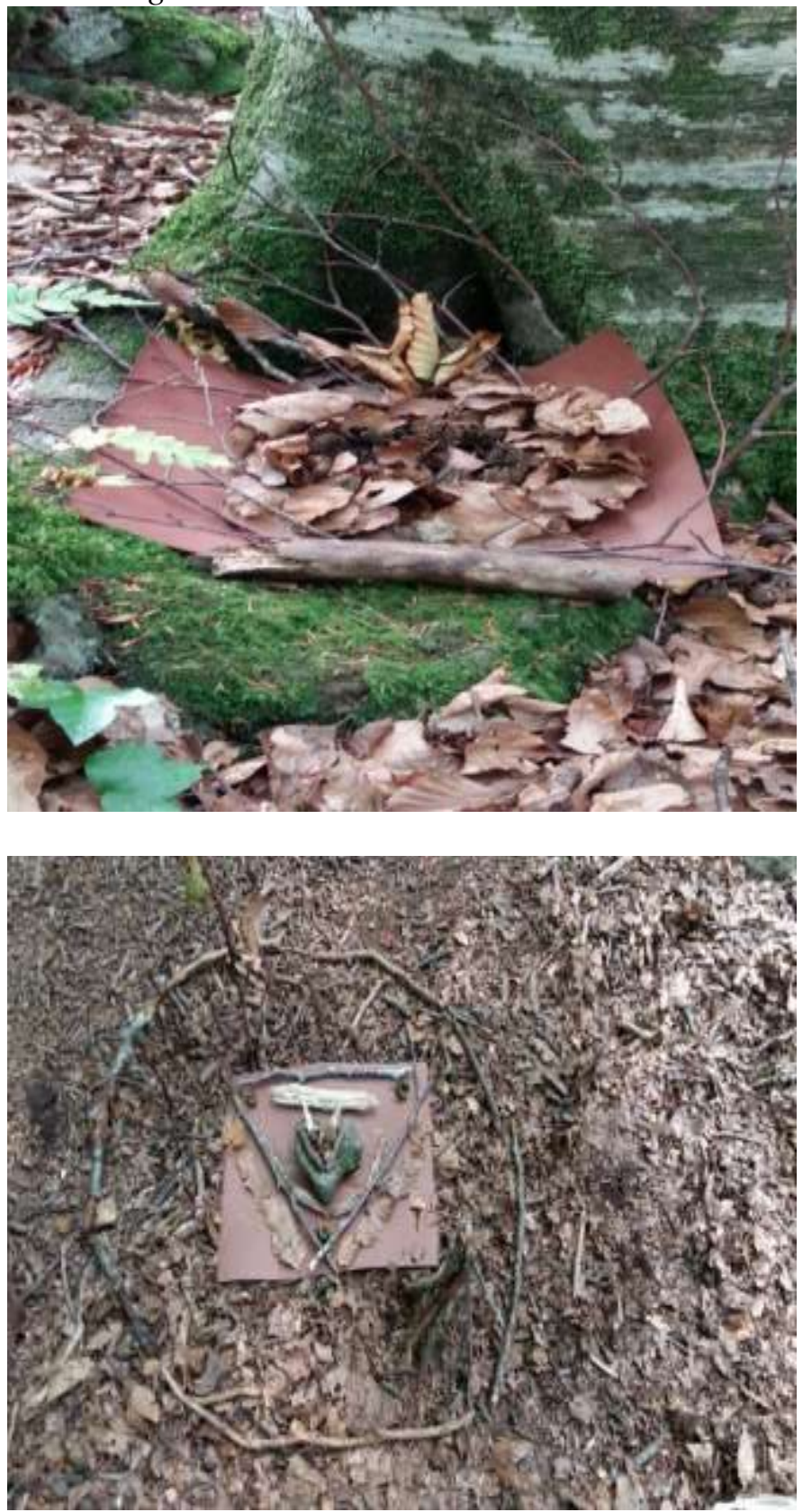

Source: Zdravković, S. (2018). The Role of Psychotherapist in the Individual Approach to the Client within the Health Tourism. TISC Tourism International Scientific Conference, Vrnjačka Banja, 3(2), $697-$ 713 
Figure 6: Active imagination-3

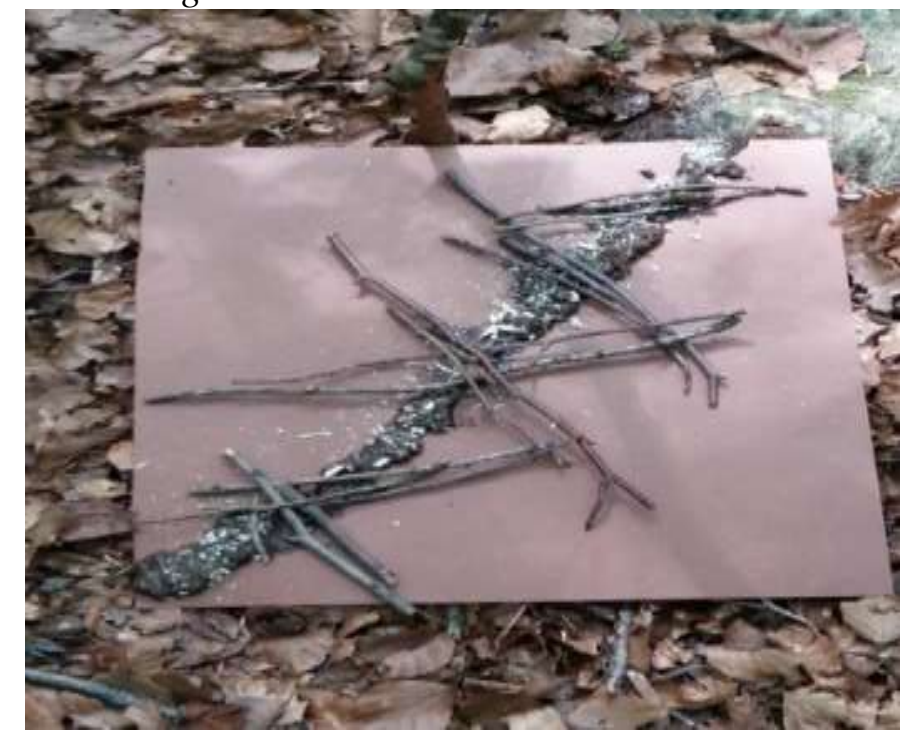

Source: Zdravković, S. (2018). The Role of Psychotherapist in the Individual Approach to the Client within the Health Tourism. TISC Tourism International Scientific Conference, Vrnjačka Banja, 3(2), 697713

This important encounter was described and discussed in detail in the authors' paper about the voice and speech quality correlates of psychological observations in Jungian active imagination experiment (Zdravković et al., 2019). There, the authors analyzed the use of active imagination within the experiment performed in the forest ambient in La Gerona national park in Spain. Active imagination (Jung, 1959) is a method applied in Jungian psychology and psychotherapy. It is a creative way, often more direct than words, of approaching the unconscious contents.

Methodology for performing active imagination experiment was the following: making figures from clay, from the forest material, drawing, painting, playing music, dancing, creative writing are some of the mediums through which active imagination could be performed. By the use of this method, the unconscious material could be formed into psychological image and embodied and, in that way, could become approachable for further work. Here are few of the products of active imagination (Figures 4, 5 and 6) made by adult participants without declared and observed mental and physical problems, during the workshop that was a result of the cooperation between a psychotherapist (a Jungian analyst, IAAP, IGAP, CIPA) from Serbia and a Forest guides' organization (ANTF) from USA. 
Before and after the experiment with active imagination, the participants' voice and speech was recorded. The authors analysed the acquired data qualitatively (a psychological evaluation of the way paricipants were feeling) and the quantitative analysis of the speech and voice parametars (a psychoacoustic evaluation). Psychological observations before and after active imagination are shown in the Table 1 and are rated with Comparison Mean Opinion Score (CMOS) scale (results shown in Figure 7).

Table 1: Psychological observations before and after active imagination

\begin{tabular}{|c|c|c|}
\hline $\begin{array}{c}\text { Parti- } \\
\text { cipant }\end{array}$ & $\begin{array}{c}\text { Psychological observations } \\
\text { before }\end{array}$ & $\begin{array}{c}\text { Psychological observations } \\
\text { after }\end{array}$ \\
\hline 1 & $\begin{array}{c}\text { She was quite excited about } \\
\text { the whole process, even } \\
\text { anxious about the unknown } \\
\text { experience. }\end{array}$ & $\begin{array}{c}\text { She became calmer, more centred, less } \\
\text { frustrated and more satisfied with } \\
\text { overcoming the anxiety and allowing } \\
\text { herself to experience something new and } \\
\text { interesting. }\end{array}$ \\
\hline 2 & $\begin{array}{c}\text { Interested with what is going } \\
\text { to happen, but quite } \\
\text { introverted and a bit reserved, } \\
\text { not too much expressive in } \\
\text { her verbal and non-verbal } \\
\text { behaviour. }\end{array}$ & $\begin{array}{c}\text { She became more vivid, more energized, } \\
\text { less reserved and encouraged to be more } \\
\text { expressive and connected with other } \\
\text { members of the group and the nature } \\
\text { around her. }\end{array}$ \\
\hline 3 & $\begin{array}{c}\text { Very curious, quite rational } \\
\text { and "in his head", with a } \\
\text { tendency of having control } \\
\text { over his emotional side. }\end{array}$ & $\begin{array}{c}\text { He became more open to his emotional } \\
\text { side, dropped few tears connected with } \\
\text { the insights he acquired, he felt joy } \\
\text { because of allowing himself to loosen } \\
\text { the control and the rational approach and } \\
\text { became more connected with the forest. }\end{array}$ \\
\hline 4 & $\begin{array}{c}\text { Curious, eager to learn } \\
\text { something new and different } \\
\text { from her way of working with } \\
\text { people, more in her intellect } \\
\text { than in emotions. }\end{array}$ & $\begin{array}{c}\text { She became satisfied because of the new } \\
\text { experience, more authentic and } \\
\text { spontaneous in her reactions, both verbal } \\
\text { and non-verbal and in better touch with } \\
\text { the forest. }\end{array}$ \\
\hline 5 & $\begin{array}{c}\text { Quite shy and introverted, } \\
\text { although interested in what is } \\
\text { going to happen, less } \\
\text { energized than others and less } \\
\text { connected. }\end{array}$ & $\begin{array}{c}\text { She become more energized, happier, } \\
\text { more open, with few important insights } \\
\text { for her future actions, more connected } \\
\text { with other members of the group and the } \\
\text { forest. }\end{array}$ \\
\hline \multirow{2}{*}{$\begin{array}{c}\text { hurious, but reserved in his } \\
\text { non-verbal expression, tired } \\
\text { because of the long business } \\
\text { week he had before coming } \\
\text { here. }\end{array}$} & $\begin{array}{c}\text { He became more energized and open, } \\
\text { more relaxed and recover for }\end{array}$ \\
\hline
\end{tabular}




\begin{tabular}{|c|c|c|}
\hline 7 & $\begin{array}{l}\text { Interested, but more on a } \\
\text { super-ficial level, wanting to } \\
\text { make a good impression onto } \\
\text { others. }\end{array}$ & $\begin{array}{l}\text { She became more satisfied, a bit more } \\
\text { authentic and connected with others. }\end{array}$ \\
\hline 8 & $\begin{array}{l}\text { Pretty frustrated and anxious } \\
\text { because of having a very bad } \\
\text { experience while arriving to } \\
\text { Spain. }\end{array}$ & $\begin{array}{l}\text { She became less frustrated and a bit } \\
\text { more open and relaxed. }\end{array}$ \\
\hline 9 & $\begin{array}{l}\text { Very motivated to participate, } \\
\text { open toward others, active, } \\
\text { but more in his rational side. }\end{array}$ & $\begin{array}{c}\text { He became more open emotionally and } \\
\text { playful, less rational and more energized } \\
\text { and spontaneous and relaxed in the } \\
\text { nature surroundings. } \\
\end{array}$ \\
\hline 10 & $\begin{array}{l}\text { Very curious about the } \\
\text { experience, eager to } \\
\text { participate, but feeling } \\
\text { physical tiredness. }\end{array}$ & $\begin{array}{l}\text { She became less tired and quite } \\
\text { recovered physically with regained } \\
\text { bodily energy, very satisfied with the } \\
\text { whole experience and more connected } \\
\text { with others and with the nature. }\end{array}$ \\
\hline
\end{tabular}

Source: Zdravković, S., Jovičić, S., Gudurić, S. (2019). The Voice and Speech Quality Correlates of Psychological Observations in Jungian Active Imagination Experiment. Journal of Psycholinguistic Research, Vol. 48, No. 4, 859-876

In the similar way psychoacoustic observations on voice quality are rated. Pearson's correlation coefficient $\mathrm{R}=0.6385(\mathrm{p}<0.05)$ shows a significant correlation between psychological and psychoacoustic ratings.

These results showed the ability to monitor psychological responses of a man based on voice analysis and that positive psychological reactions in participants' verbal and non-verbal reactions could be seen after active imagination combined with the forest medicine approach and that they could be registered by the phenomenological-descriptive analysis.

Luckily, in this difficult time of COVID-19, when major changes strike us almost on every step we make, health tourism and a forest medicine within it, represent a wonderful bright light in the darkness of liminality we are going through. We can still go to forests, make long walks with respect to a "social distance" that bothers us so much in the cities. That distance in the forest environment gets a completely different meaning. It allows us to get in better contact with our inner nature as well as with the nature that surrounds us. Touching trees, ground and plants does not put us into danger. Masks are not hiding a major part of our faces since a distance is big enough and we are outdoor. The air is not polluted and dangerous. A 
relaxing atmosphere with relaxing sounds, fragrances, sensations and sights is calling us to reconnect with our healthy and creative parts.

Figure 7: Results for active imagination rating and voice quality rating

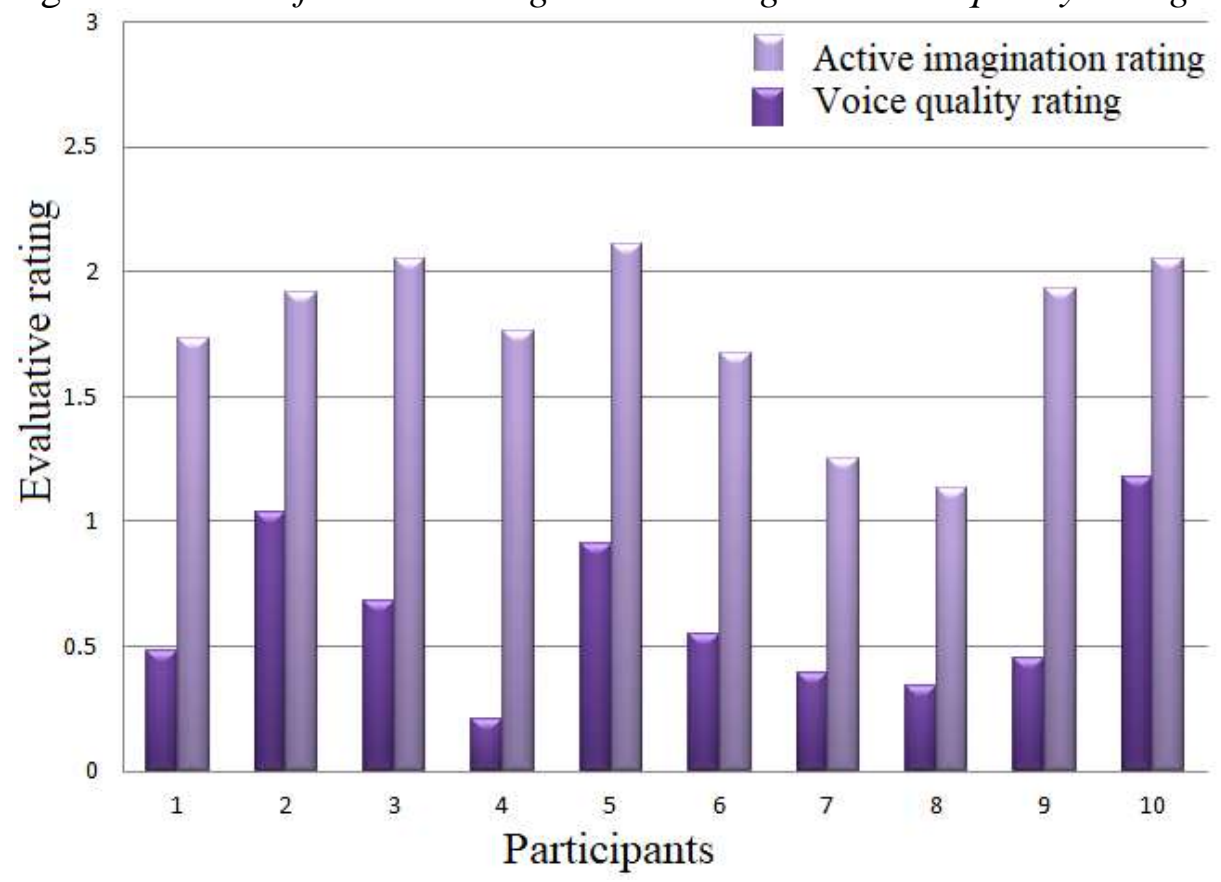

Source: Zdravković, S., Jovičić, S., Gudurić, S. (2019). The Voice and Speech Quality Correlates of Psychological Observations in Jungian Active Imagination Experiment. Journal of Psycholinguistic Research, Vol. 48, No. 4, 859-876

\section{Psychotherapy before and in the time of COVID-19}

The situation within the field of psychotherapy is quite different now. Before the situation when a COVID-19 pandemic started, all depth psychotherapies had certain features and settings. It was the same situation within Jungian analysis as well. A psychotherapeutic session was being held in vivo in the therapist's consulting room with a patient who was physically present. They were usually sitting and looking at each other. The face and body were visible in such a way that a non-verbal communication could be followed too. The analyst was able to see the patient and the opposite. They were meeting on a regular basis. A patient was undertaking a journey towards his analyst's place before each session during which he or she could psychologically as well as physically get out of his world and 
gradually arrive and enter into psychotherapist's world. The opposite process was taking place when the session was over. A therapist was not seeing and entering into the patient's space (house). Both of them had a possibility to follow the expressions of their faces and the postures of their bodies while they were talking. The session has been held at the same place. Only in some special circumstances communication was being held online via WhatsApp, Viber, Skype, phone, etc.

Since the COVID-19 pandemic started, the psychotherapeutic sessions continued to be held and the processes of patient's individuation to unfold. The essence of the relation between the therapeutic dyad stayed the same. Dreams and fantasies are still being analyzed, transference/countertransference feelings noticed and discussed. Sessions are being held on a regular basis with the same length. On the other side, for more than a year, the circumstances in which the analytic encounter is being held and the way the psychotherapeutic temenos looks today are changed greatly.

The new analytical of psychotherapeutic setting most often implies online communication. In this situation, the analysts as well as their patients were confronted with few paradoxes. One of them is connected with a distant closeness or a close remoteness. At the same time, the persons engaged in analysis are seeing each other's face in a short distance on the mobile screen or on the computer monitor. That is much lesser distance comparing to the one in vivo. Looked from the other side, a patient could be at the other part of the city, country or world. Obligation of wearing masks in the health institutions does not enable people to see each other's whole face. This could evoke a sense of uneasiness, discomfort and anxiety.

Then, there is the absence of a body. We see the other on the screen, usually a head and shoulders, but the body with all its nonverbal communications is not available and approachable. The body is being missed a lot both from a diagnostic as well as from a therapeutic perspective. Tactility is absent too. Patients could not shake their hands on their way to or from the analyst. The valuable role of silence and the pauses in speech is hugely reduced. Not being physically present in the same room and being faced with a face in the close plane, press people to enlarge the quantity of speech at the account of the silence and pauses. This important way of getting in touch with one's inner world of feelings, sensations and introspections is diminished. It is well known how much Jung valued the silence (Zdravković \& Jovičić, 2020). 
Figure 8: Active imagination-4

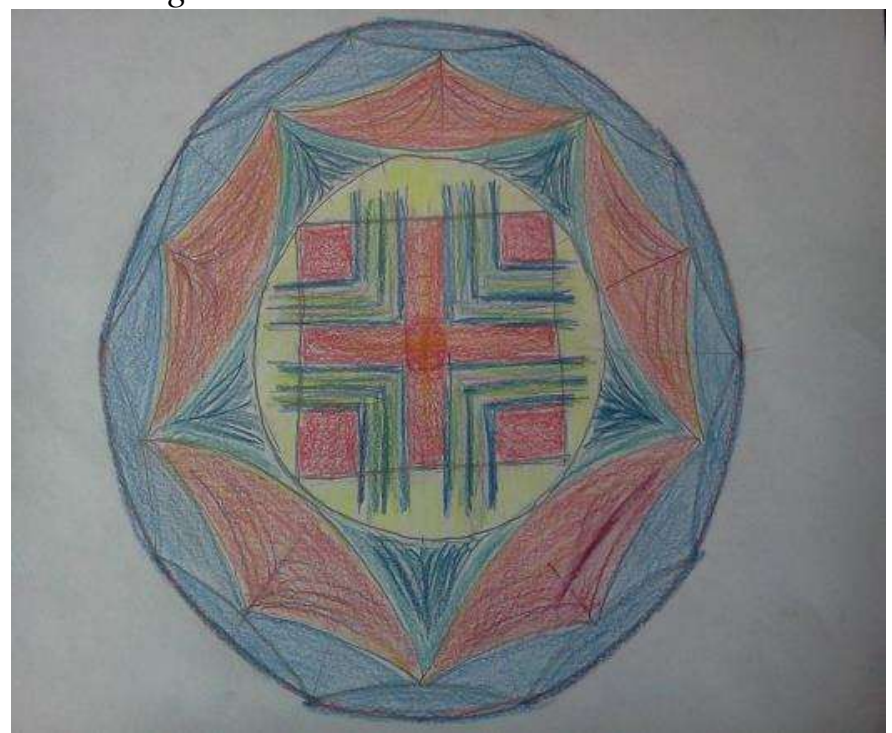

Source: Zdravković, S. (2020). Active imagination and dreams - creative interplay during analysis. C. G. JUNG-FORUM e-Journal der OGAP, Vol. 10, 21-34

A method of active imagination that can begin with the silence while getting deeper into the inner world was already mentioned in the context of forest medicine and health tourism. Here is the product of active imagination (Figure 8) a patient $\mathrm{N}$. made close to the beginning of his analysis. In the central part of the image, he draws a cross. He was not content at all with the colors he chose and with the shapes he made. He thought that the drawing was very rigid and sterile. He was not in a good contact with his inner world, with his inner nature. He was experiencing himself as not flexible enough, as too much in his head and to little in his feelings. He was mostly wearing black color, he was feeling depressed and was not much open to the big variety of emotions.

After working on his dreams, history etc, his products of active imagination started to change together with his experience of himself. On the following image, it could be seen how the shapes and the colors started to change. The "good fairies" - Flora, Fauna and Merry-weather visited him and "changed the curse" of being always in his thoughts and dressed (even psychologically) only in dark colors. The images of nature and life started to emerge (Figure 9). After a while, wholly blossomed, looking almost three-dimensional, flower emerged (Figure 10). N. was in a much better mood, more open towards his emotional and creative parts. 
Figure 9: Active imagination-5

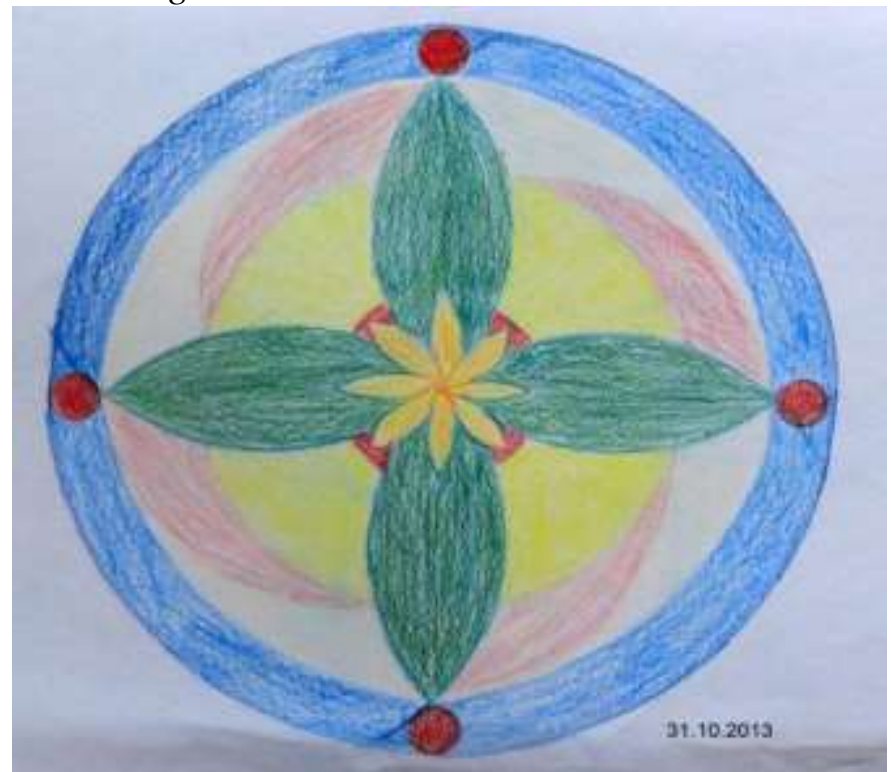

Source: Zdravković, S. (2020). Active imagination and dreams - creative interplay during analysis. C. G. JUNG-FORUM e-Journal der OGAP, Vol. $10,21-34$

Figure 10: Active imagination-6

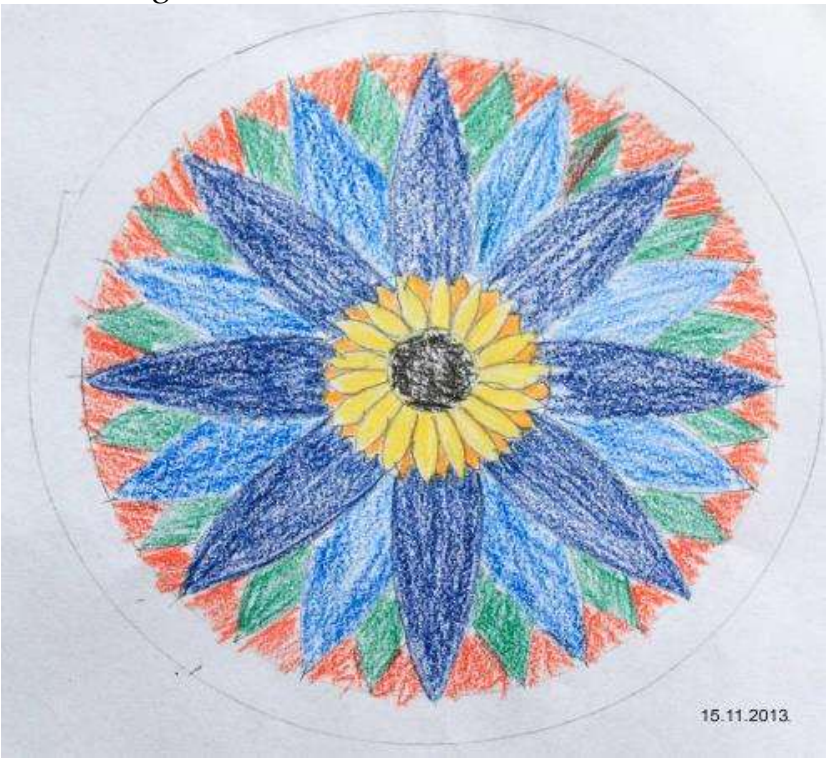

Source: Zdravković, S. (2020). Active imagination and dreams - creative interplay during analysis. C. G. JUNG-FORUM e-Journal der OGAP, Vol. $10,21-34$ 
As the process of analysis was getting to an end, N. was not being depressed anymore. He was much more into contact with his emotions and with his creativity (Zdravković, 2020). He started to write again after a very long period. Writing was something that he buried long time before, in his puberty. During analysis he reconnected with his love and inspiration for writing. He was feeling younger and more in contact with his true nature.

Figure 11: Active imagination-7

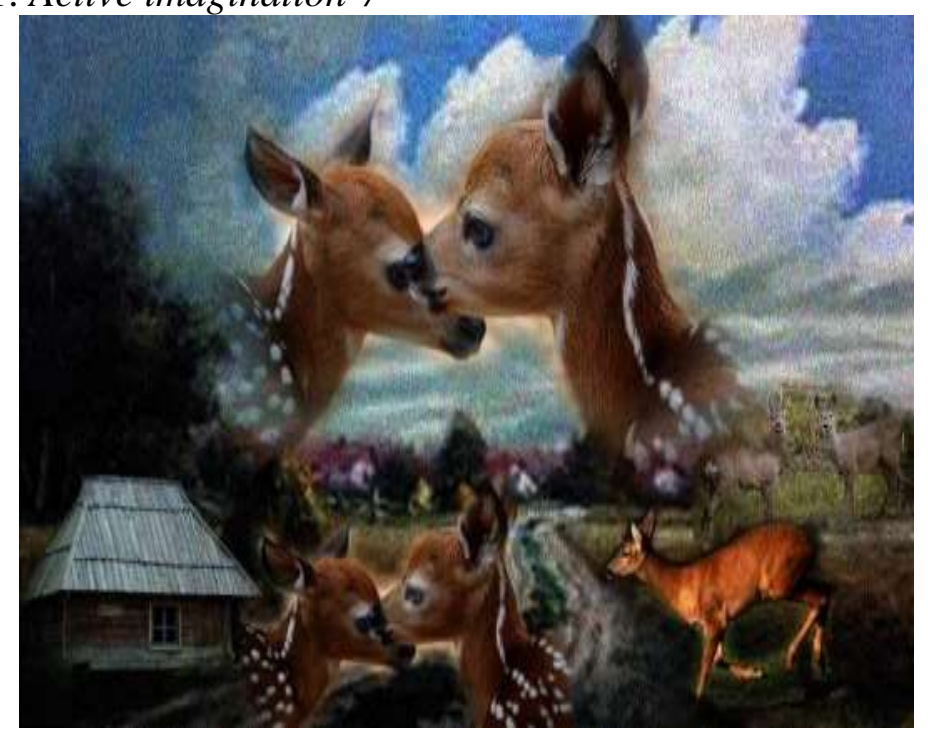

Source: Zdravković, S. (2020). Active imagination and dreams - creative interplay during analysis. C. G. JUNG-FORUM e-Journal der OGAP, Vol. $10,21-34$

The last collage that he made (Figure 11) was based on a dream. He was in the nature, close to the house of his ancestors. It was a beautiful weather in an amazing atmosphere. A young doe came to him. He gently cuddled her and she did not run away from him. She stayed and looked at him with her gorgeous big eyes. He had a numinous experience of a great importance. He felt in a perfect harmony with a doe and with a nature that was around him.

\section{Conclusion}

Psychotherapy and health tourism - Joined efforts

The goal of the paper was to examine newly established circumstances caused by COVID-19 pandemic as well as their influence on psychotherapy and health tourism. We can see how both forest medicine within health 
tourism and psychotherapy were helping and could continue to help people to live more qualitative and happier lives. The changes that stroke us during the time of Covid-19 had and will continue to have huge effects and consequences in lot of areas. In spite of the necessary adjustments, psychotherapy continues to get people in contact with their inner nature and thus helping them to heal their mental health. Health tourism, on its side also continues to cure and heal people depending on their needs. The authors arrived to the conclusion, based on the theoretical research and on their own clinical and research experience, that joined together, experts using some of the methods from the field of psychotherapy (like active imagination) and from the field of health tourism (and forest medicine) could do a lot in the time of COVID-19. The benefits of spending time in the forest are unquestionable, but the benefits could be more profound and much more lasting if we enhance it with the expertise and knowledge from the field of depth psychotherapies, more precisely, from Jungian analysis.

\section{Acknowledgements}

This study was supported by grants OI178027 from the Ministry of Education, Science and Technological Development of the Republic of Serbia.

\section{References}

1. Crowther, C., Haynes, J., Newton, K. (1998). Myth and fairytales. In I. Alister, C. Hauke, (Eds.), Contemporary Jungian analyses (pp. 209-228). Routledge, London and New York.

2. Digby Scott, (2019), Master the Liminal, https://digbyscott.com/2019/ 09/26/master-the-liminal/, (20 January 2021)

3. Fiery, K.H. (1991). Jungian psychiatry, Daimon, Verlag, Switzerland.

4. Gaillard, C. (2006). The Arts. In R. Papadopoulos, (Ed.), The handbook of Jungian psychology (pp. 324-376). Routledge, London and New York.

5. Jung, C.G. (1954). The Development of Personality, Routledge and Kegan Paul, London and Henley.

6. Jung, C.G. (1959). The Archetypes and the Collective Unconscious, Routledge and Kegan Paul, London. 
7. Jung, C.G. (1960). The structure and dynamics of the psyche, Routledge and Kegan Paul, London and Henley.

8. Learning Spaces, (2021), The Liminal Space, http://aspacetoinspire. weebly.com/the-liminal-space.html, (20 January 2021)

9. Rajković, M., Jovičić, S.T., Grozdić, Đ. T., Zdravković, S., Subotić, M. (2018). A note on acoustic features in pitch contours for discrimination of happiness and anger. Acta Acustica United with Acustica, Vol. 104, No. 2, 369-372.

10. Samuels, A. (2000). A Critical Dictionary of Jungian Analysis, Routledge, London and New York.

11. Stein, M. (1996). Practicing Wholeness, A Chiron Publication, Continuum, New York.

12. Stein, M. (2003). In MidLife, Spring Publications, Inc., Putnam, Connecticut.

13. Stein, M. (2006). The Principle of Individuation, Chiron Publications, Wilmette, Illinois.

14. Zdravković, S. (2020). Active imagination and dreams - creative interplay during analysis. C. G. JUNG-FORUM e-Journal der OGAP, Vol. 10, 21-34.

15. Zdravković, S., Jovičić, S., Gudurić, S. (2019). The Voice and Speech Quality Correlates of Psychological Observations in Jungian Active Imagination Experiment. Journal of Psycholinguistic Research, Vol. 48, No. 4, 859-876.

16. Zdravković, S. (2018). The Role of Psychotherapist in the Individual Approach to the Client within the Health Tourism. TISC - Tourism International Scientific Conference, Vrnjačka Banja, 3(2), 697-713.

17. Zdravković, S., Jovičić, S. (2020). The importance of speech pauses for psychotherapeutic and forensic observations. International scientific conference "Archibald Reiss days", Belgrade, Vol. 10, 513-524. 